\title{
PReS-FINAL-2195: The comparison of the efficacy of once and twice daily dosage of colchicine in pediatric patients with Familial Mediterranean Fever
}

\author{
A Polat, C Acikel, B Sozeri', I Dursun, O Kasapcopur, H Peru, I Dokurel, H Poyrazoglu, S Bakkaloglu, A Delibas, \\ Z Ekinci, NA Ayaz, Y Kandur, E Unsal, B Makay, F Gok, S Ozen, E Demirkaya
}

From 20th Pediatric Rheumatology European Society (PReS) Congress

Ljubljana, Slovenia. 25-29 September 2013

\section{Introduction}

Familial Mediterranean Fever (FMF) is the most common periodic fever syndrome, characterized by recurrent fever and serositis attacks. Colchicine is the treatment of choice. Colchicine is given in two or three divided doses due to its side effects. It has been stated that colchicine unresponsive patients are in fact non-compliers because there is an inverse relationship between daily dosage and patient compliance.

\section{Objectives}

In this study, it was aimed to investigate whether the once daily dosage would be as effective as twice daily dosage regimen in reducing disease symptoms and inflammation both in clinical and laboratory parameters addition to manifesting with similar side effects.

\section{Methods}

Seventy-nine patients between 5 and 16 years of age with a clinical and genetically confirmed diagnosis of FMF and who had never received colchicine were included in the study. The drug was started in one or two doses randomly. A total of 42 patients received colchicine in once daily dosage while 37 patients had in twice daily dosage. The clinical, laboratory parameters and drug side effects were assessed on three clinical visits two months apart.

FMF Arthritis Vasculitis and Orphan Disease Research in Paediatric Rheumatology (FAVOR), Ankara, Turkey 


\section{Disclosure of interest}

None declared.

Published: 5 December 2013

doi:10.1186/1546-0096-11-S2-P185

Cite this article as: Polat et al:: PReS-FINAL-2195: The comparison of the

efficacy of once and twice daily dosage of colchicine in pediatric

patients with Familial Mediterranean Fever. Pediatric Rheumatology 2013

11(Suppl 2):P185.

Submit your next manuscript to BioMed Central and take full advantage of:

- Convenient online submission

- Thorough peer review

- No space constraints or color figure charges

- Immediate publication on acceptance

- Inclusion in PubMed, CAS, Scopus and Google Scholar

- Research which is freely available for redistribution 